Article

\title{
Coupling Historical Maps and LiDAR Data to Identify Man-Made Landforms in Urban Areas
}

\author{
Martino Terrone ${ }^{1}$, Pietro Piana ${ }^{2}$, Guido Paliaga ${ }^{3, *(D)}$, Marco D’Orazi $^{4}$ and Francesco Faccini $^{1,3}$ (D) \\ 1 Department of Earth, Environmental and Life Sciences, University of Genoa, 16132 Genoa, Italy; \\ martino.terrone@edu.unige.it (M.T.); faccini@unige.it (F.F.) \\ 2 Department of Political Sciences, University of Genoa, 16124 Genoa, Italy; pietro.piana@edu.unige.it \\ 3 National Research Council, Research Institute for the Geo-Hydrological Protection, 10135 Turin, Italy \\ 4 Direzione Sistemi Informativi del Comune di Genova, Municipality of Genoa, 16149 Genoa, Italy; \\ mdorazi@comune.genova.it \\ * Correspondence: guido.paliaga@irpi.cnr.it
}

Citation: Terrone, M.; Piana, P.;

Paliaga, G.; D'Orazi, M.; Faccini, F.

Coupling Historical Maps and LiDAR

Data to Identify Man-Made

Landforms in Urban Areas. ISPRS Int

J. Geo-Inf. 2021, 10, 349. https://

doi.org/10.3390/ijgi10050349

Academic Editors: Motti Zohar and Wolfgang Kainz

Received: 31 March 2021

Accepted: 14 May 2021

Published: 18 May 2021

Publisher's Note: MDPI stays neutral with regard to jurisdictional claims in published maps and institutional affiliations.

Copyright: (c) 2021 by the authors. Licensee MDPI, Basel, Switzerland. This article is an open access article distributed under the terms and conditions of the Creative Commons Attribution (CC BY) license (https:// creativecommons.org/licenses/by/ $4.0 /)$.

\begin{abstract}
In recent years, there has been growing interest in urban geomorphology both for its applications in terms of landscape planning, and its historical, cultural, and scientific interest. Due to recent urban growth, the identification of landforms in cities is difficult, particularly in Mediterranean and central European cities, characterized by more than 1000 years of urban stratification. By comparing and overlapping 19th-century cartography and modern topography from remote sensing data, this research aims to assess the morphological evolution of the city of Genoa (Liguria, NW Italy). The analysis focuses on a highly detailed 1:2'000 scale map produced by Eng. Ignazio Porro in the mid-19th century. The methodology, developed in QGIS, was applied on five case studies of both hillside and valley floor areas of the city of Genoa. Through map overlay and digitalization of elevation data and contour lines, it was possible to identify with great accuracy the most significant morphological transformations that have occurred in the city since the mid-19th century. In addition, the results were validated by direct observation and by drills data of the regional database. The results allowed the identification and quantification of the main anthropic landforms. The paper suggests that the same methodology can be applied to other historical urban contexts characterized by urban and architectural stratification.
\end{abstract}

Keywords: urban geomorphology; anthropogenic landforms; old maps; contour lines; Genoa

\section{Introduction}

Detailed knowledge of landforms, both natural and human, contributes to the understanding and awareness of geo-hydrological risk [1-7]. However, these landforms are often no longer immediately identifiable, particularly in densely urbanized contexts, where they have been progressively obliterated by urban growth [8,9]. This is the case of Mediterranean cities, characterized by ancient urban history, where the identification of the various phases of landscape modification is crucial for urban planning. This process helps us to identify hidden or neglected risks due to diverted or covered streams and superficial landforms (slope cuttings, retaining walls) [10-17].

Urban geomorphology $[8,14,18,19]$ is a new discipline aimed at investigating and quantifying urban landscape changes under a historical perspective, for instance, by comparing multi-temporal cartographies in order to identify landforms modifications and volumes' shape changes through centuries.

However, while precision and cartographical accuracy of a modern cartographical product are defined by standardized and known validation processes, the same concept does not apply for historical cartography, since map making techniques have changed through time and often lack precision and accuracy [19-21]. 
This makes it necessary to study their evolution and production techniques [21-24]. More particularly, maps produced between the late 18th and the early 19th century progressively lost their links with landscape art. Increasingly, they were produced using scientific surveying techniques, which entailed astronomic studies as well as geodetic and topographic field observations [25]. At the same time, these maps depict landscape settings of the pre-industrial age, before urban sprawl and substantial landforms modifications took place. In this period, the map is conceived as a mathematical representation of the landscape, the adoption of contour lines being a particularly meaningful example [26].

Traditionally associated with the military field, maps went through substantial technological improvements in the 18th century, when a new cartography based on modern instruments and geometric rules was increasingly functional to national states. The first systematic mapping of France on a scale of 1:86,400 using a measuring apparatus was carried out during the 18th century by members of the Cassini family [27]. The British Ordinance Survey undertook national mapping from 1791 [28], and topographical drawing and mapping were an important part of army and navy officer's education in 18th-century military schools. Cartography was also functional to the establishment of overseas colonial empires in the 18th and 19th century, and to the modernization of newly conquered areas, as was the case of Italy in the Napoleonic period [29]. The methodology of production was used and improved until the 1980s when significant adoption of digital techniques in data acquisition has emerged [30,31]. Particularly valuable examples of precise geographical representation in Italy are detailed cadastral plans of some pre-unitary states, including the Grand Duchy of Tuscany, the Kingdom of Lombardy-Venetia, the Sardinian Kingdom, and the Kingdom of the Two Sicilies [32,33], whose astronomic observatories allowed optimal geodetic measurements, similarly to those in northern and central Europe states.

In Liguria (north-western Italy), the first example of fairly accurate cartographical representations are the maps by Matteo Vinzoni, appointed official surveyor of the Commissari della Sanità of the Republic of Genoa in 1722. By using the alidade and the plane table, Vinzoni depicted the whole Ligurian coast in his "Pianta delle due Riviere della Serenissima Repubblica di Genova divise ne' Commissari della Sanità". In addition to representing one of the first systematic surveys of an entire state in the Italian context, Vinzoni's work is used as one of the sources to monitor coastal dynamics in Liguria [13,32]. The main cartographical product of early 19th-century north-western Italy was the Carta degli Stati Sardi in Terraferma di S. M. il Re di Sardegna, divided into 91 sheets on a scale of 1:50.000, of which 86 were published between 1851 and 1859 [33,34]. The map is the product of accurate field surveys carried out in the previous decades by the Piedmontese cartographers, who produced a series of 112 highly accurate manuscript maps (1:9'450, 1:10'000, and 1:20'000) commonly called Minute di Campagna.

With the unification of the Kingdom of Italy, the newly founded Istituto Geografico Militare (IGM) (1861) carried out a complete mapping of the entire Italian territory at various scales $\left(1: 10^{\prime} 000 ; 1: 50^{\prime} 000 ; 1: 100^{\prime} 000\right)$ using the technique of contour lines for the depiction of elevation [35]. In order to cover the entire Italian territory, the Bessel ellipsoid was adopted as datum and the reference median was that of Monte Mario $12^{\circ} 27^{\prime} 08,400^{\prime \prime}$ East of Greenwich.

This work aims to assess volumetric changes of anthropic landforms in an urban environment in the last two centuries in the city of Genoa (NW Italy) through computational analysis and cartographical comparison. This time frame is considered appropriate, as maps produced in the early 19th century are the oldest available documents for a scientific reconstruction of pre-urban sprawl morphology. This means that the earliest mapped anthropic landforms represent the total amount of pre-existing elements as a result of the stratification of several urban phases, particularly of the Middle Ages and Modern Age.

In particular, this paper could be divided into two targets:

(1) Quantifying the potential errors and the intrinsic accuracy of the analyzed old map;

(2) Creating an old Genoa digital terrain model and quantifying urban transformations by the underlying elevation gradient with the modern digital terrain model. 


\section{Materials and Methods}

\subsection{Study Area}

Genoa is a port city of the Mediterranean and capital of Liguria (north-western Italy). The municipality, whose current size dates back to the 1926 "Grande Genova" project, is $240.29 \mathrm{~km}^{2}$ wide and the coastline $35 \mathrm{~km}$ long. The most ancient core of the city, the yellow area in Figure 1, was smaller (c. $11.45 \mathrm{~km}^{2}$ ) and was roughly located between the city's two main streams: the Bisagno in the eastern part, and the Polcevera in the West. From a geological point of view, the study area is largely constituted by marly limestones, marls, and clays in Flysch sequences of Upper Cretaceous, while the western part, in the Polcevera Valley, is dominated by shales of Lower Cretaceous [36-38]. The two formations are found both as outcrops and bedrock. Another important lithotype, today largely hidden by the urban structure, is constituted by stiff fissured Pliocene clays, exclusively found in the historical center [37-42]. Morphology is characterized by many small and steep catchments, mostly oriented orthogonally to the coastline, originating from the neotectonic activity [42].

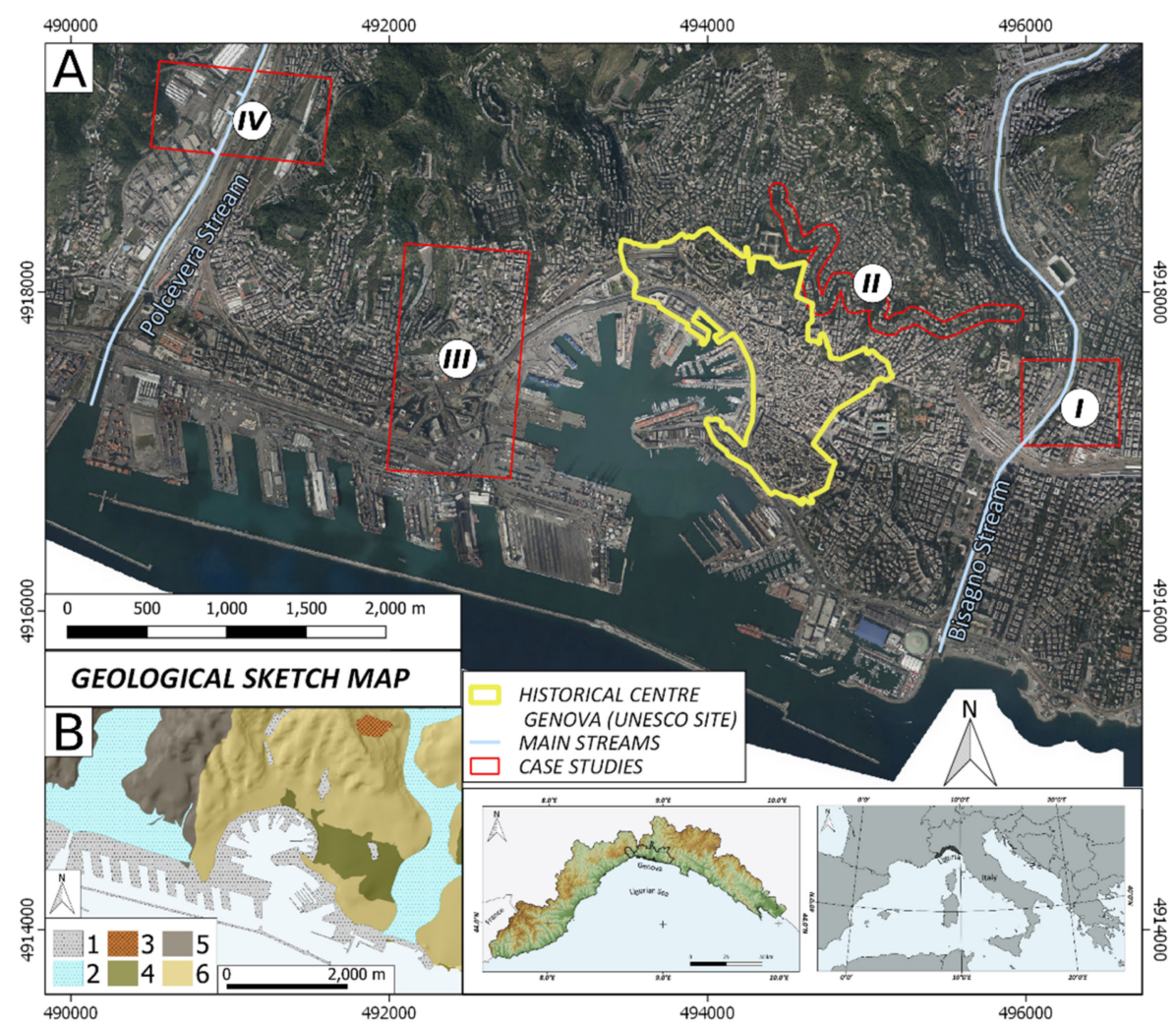

Figure 1. (A) Study area and areas of interest. (B) The geological sketch map box: (1) waterfront embankments; (2) alluvial deposits; (3) slope deposits; (4) stiff fissured clays; (5) shales; (6) marly limestone with clayey shales interlayers.

The first permanent settlement dates back to the pre-Roman period. In the Middle Ages, Genoa developed around the old city core with an East-West direction along the coastline [43]. Urban sprawl over the hills, with a South-North direction, and along the coast developed in more recent times [44] (Figure 2). In the early 19th century, the two main valleys, the Polcevera to the West and the Bisagno to the East, were characterized by an agricultural landscape with a dense pattern of small fields across the floodplain and terraces over the slopes with a prevalence of vineyards and olive orchards $[45,46]$. Terraces are only partly visible in the current landscape and have been largely obliterated by more recent urban structures, decametric retaining walls, and high blocks of flats of the second half of the 20th century [47]. Urban expansion brought hydraulic works in the two valleys, with progressive narrowing of the riverbeds and the establishment of new 
urban areas in the floodplains in the early 20th century up to the 1930s [12]. It is estimated that loss of agricultural surfaces between 1820 and 2014 in the Bisagno Valley was 57\%, while woodland and new urban areas increased respectively by $248 \%$ and $750 \%$ [45]. In the second post-war period, the Promontory of San Benigno, exploited for the extraction of marly limestone as building material from the Middle Ages, was completely excavated. The complete removal of San Benigno Promontory allowed territorial continuity between Genoa center and its western suburbs, with intense urban saturation of many areas, including the former rock quarry [34].

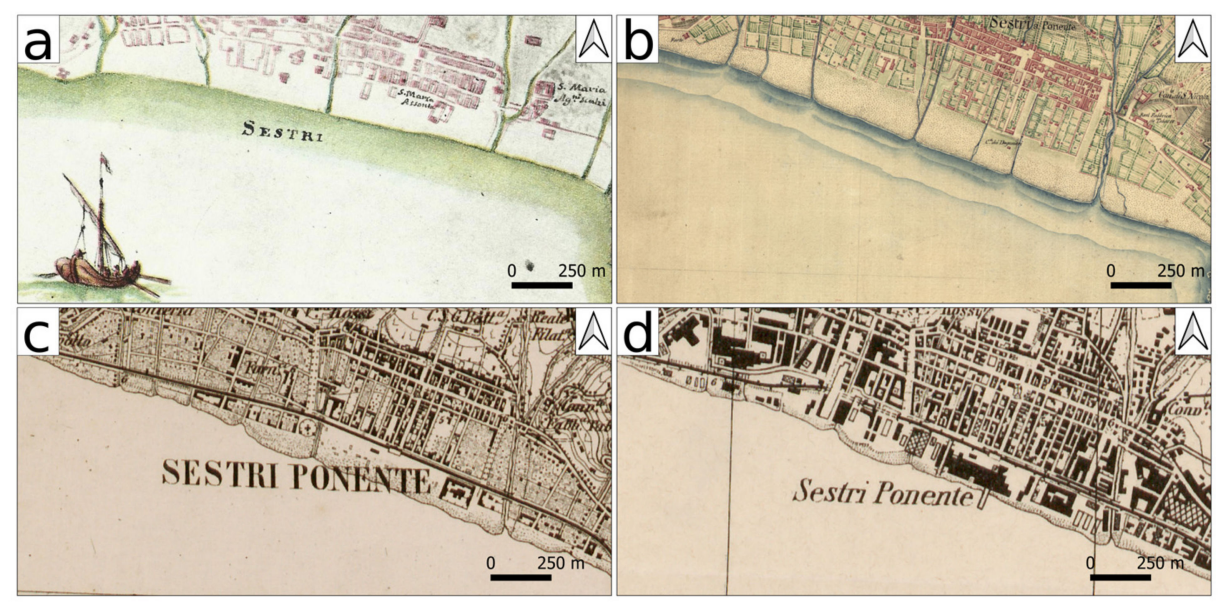

Figure 2. Urban sprawl in western Genoa (a) Vinzoni (1773) “Il dominio della Serenissima Repubblica di Genova in terraferma (Riviera di Ponente)"; (b) Carta degli Stati Sardi in Terraferma di S. M. il Re di Sardegna "Minute di campagna scale", scale 1:9,450 period 1815-1823; 1:25,000 scale topographic map of the Italian Military Geographic Institute of 1878 (c) and 1934 (d).

\subsection{Materials}

Analyzed material can be divided into two subgroups: historical cartography and current cartography.

The most important document is the "Carta Generale di Difesa di Genova" by engineer Ignazio Porro (1848). For the purpose of this research, we analyzed the digitalized version of black and white photographs of the 74 original plates (scale 1:2'000) of the "Carta Generale di Difesa di Genova" depicting a large part of the current urban area. Porro, who was engaged by the Kingdom of Sardinia for the production of the map, can be considered as a pioneer of topographical surveying and is the inventor of the Porro prism for binoculars.

The map represented with high detail the system of military fortifications and the morphology of the Genoa area, providing topographical information for urban planning aimed at improving the military defenses of the city. Starting from data acquired by Napoleonic topographers and unpublished documents by astronomer Baron De Zach (1816-1817) and with the help of engineer Giulio D'Andreis, Ignazio Porro carried out a new triangulation using mountains around Genoa as reference points and applying for the first time in Italy the tacheometry technique, which he appositely improved for the purpose of this project [48].

The final work consists of 74 plates on a scale of 1:2'000 with a reference system related to the Lanterna (Lighthouse of Genoa Harbour), with 10-m-interval contour lines.

This cartographical product is one of the first Italian examples of topographical representation with contour lines. Overall, it is a metric planimetry based on relative coordinates and with the North direction coaxial to the plates' vertical squares

The area analyzed in this research is in the central part of the city and the coast nearby and is covered by 7 of the 74 plates produced by Porro. These are plates $n^{\circ} 42,52,53,62$, 63, 72, and 73, according to Porro's numbering system. 
Notably, the analysis focuses on particularly interesting sections from a historical and urban geomorphological point of view (see Figure 1): (I) Sant'Agata Old Bridge (included within sheets $n^{\circ} 42$ and 52); (II) Circonvallazione a Monte (included within sheets $n^{\circ} 52$, 53, 63); (III) San Benigno Promontory and via Digione area (both included within sheets $\mathrm{n}^{\circ} 62$ and 72; and (IV) Polcevera Viaduct area (i.e., Morandi Bridge area), entirely included within sheet $\mathrm{n}^{\circ} 73$.

Cases I (Sant'Agata Old Bridge) and IV (Polcevera Viaduct) are located in alluvial plains respectively of the Bisagno and Polcevera Streams, while II (Circonvallazione a Monte) and III (San Benigno Promontory and via Digione area) are hillside case studies, very significant for the substantial urban and morphological modifications they went through during the years, particularly due to rock excavation.

Modern cartography consists of sheets of the Regional Technical Map of Liguria on a scale of 1:5'000 ("Carta Tecnica Regionale" ed. 2007), digital terrain models (DTMs) with a $1-\mathrm{m}$ resolution and equivalent scale of 1:1'000, and orthophotos with a 10-cm resolution. The last two constitute the LiDAR aerial survey that Genoa Municipality commissioned in September/October 2018 across the municipal area (Figure 3).

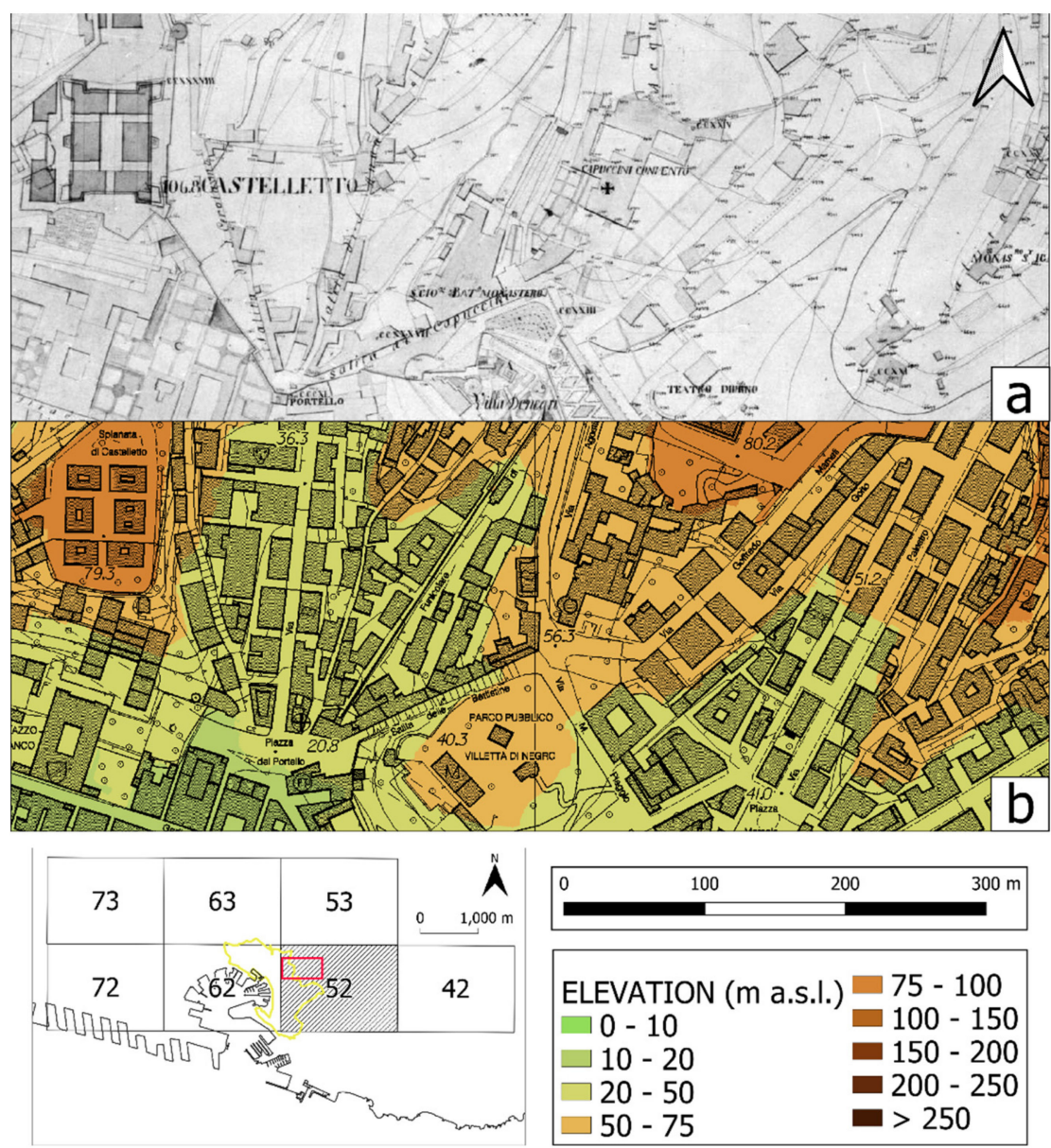

Figure 3. (a) Porro Plate $n^{\circ} 52$. (b) The same area today, overlay of Regional Technical Map and DTM LiDAR.

In addition, stratigraphic information from the database of Regione Liguria [49] and boreholes promoted by the Special Commissioner for the reconstruction of Polcevera viaduct, after the Morandi Bridge disaster [50], were used. These are fundamental data sources in order to reconstruct the deepness of the contact interface between landfill material and natural rock/sediment. These point data were integrated with the digitalized contour lines and are the input for interpolation calculation. 


\subsection{Methods}

The methodology is summarized in Figure 4. Two different GIS software were used, QGIS and GRASS, while the accuracy of the old cartography was defined with MapAnalyst.

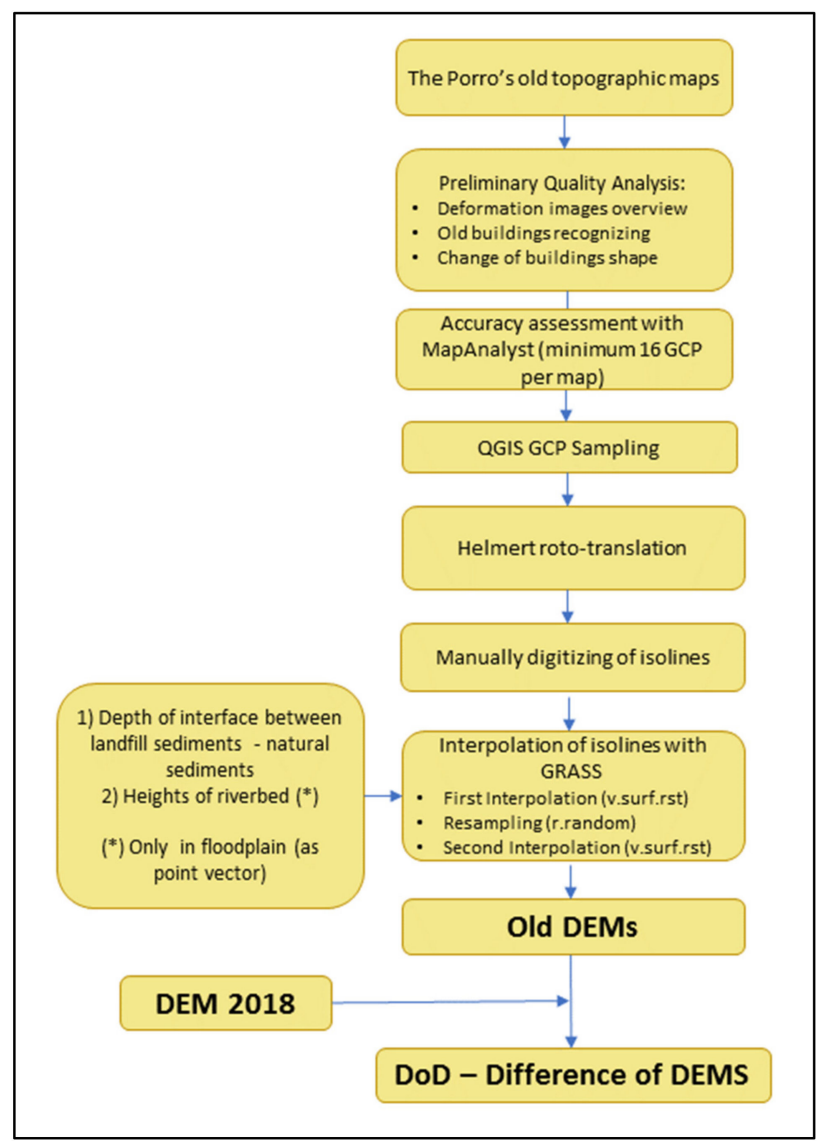

Figure 4. Methodology workflow.

QGIS was used for the georeferencing and digitalization of contour lines, while GRASS was used to generate the digital elevation model (DEM) and for statistical and algebraic analysis of the difference of DEMs (DoDs) system [51-54].

The analysis initially seeks to define the intrinsic quality of maps, considering that the accuracy error of old maps on the $\mathrm{x}-\mathrm{y}$ plane $\left(R M S E_{H}\right)$ is given by the sum of various factors summarized in the following relation (1):

$$
R M S E_{H}=\left(R M S E_{s}^{2}+M \cdot R M S E_{m}^{2}+M \cdot R M S E_{d}^{2}\right)^{0.5}
$$

where $R M S E_{S}$ is the error introduced by the ground survey, $R M S E_{m}$ is the map error, $R M S E_{d}$ is the digitization error, and $M$ is the map scale factor $[55,56]$.

As Porro himself described in his relation [57], topographical surveying was affected by an azimuthal instrumental error (RMSE) of $0^{\circ} 0^{\prime} 70^{\prime \prime}$, which meant a real deviation of $0.33 \mathrm{~m}$ on the $x-y$ plane at a distance of $1 \mathrm{~km}$.

Moreover, digital images are the product of a process of paper maps photography that has very likely produced perspective distortions $\left(R M S E_{d}\right)$. In addition, it has been observed that original images show deformations also due to paper deterioration processes $\left(R M S E_{m}\right)$.

- Accuracy analysis with MapAnalyst

The first passage entailed a monitor comparison between the old map and the current orthophoto/topographical map aimed at identifying the perimeters of medieval, Renais- 
sance, and 18th/19th-century palaces still found in Genoa's urban fabric. Once reference points of both maps were found, ground point control (GCP) positioning was carried out. These are common points between plates of the Porro Map and the current cartography, using firstly orthophotos and secondly OpenStreetMap only as auxiliary images for references of place names.

MapAnalysts simulates a georeferencing process, which consists in imposing a geographical reference system known to the target image. This dislocation causes variable image distortions depending on the desired reference system. However, the output provided by MapAnalyst is not a ground control point (GCP) but a statistical basis on the old map accuracy compared to the modern one.

For this analysis, three geo-referencing algorithms, available in MapAnalyst, were applied: Linearised Helmert, the Affine transformation with 5 parameters, and the Affine transformation with 6 parameters.

- $\quad$ Georeferencing and contour lines digitalization with QGIS

Once the statistical basis was obtained, the same procedure was applied using QGIS, identifying for each image the same configuration and the same number of GCPs allocated in MapAnalyst.

Images in QGIS were georeferenced with the linearized Helmert algorithm. This algorithm does not distort an old image; rather, it roto/translates it, minimizing the deviation between the old image and the geo-referenced one. The adopted reference system is Gauss-Boaga Roma 40 (EPSG 3003).

In general, it is possible that some points might be higher than RMSE. In this case, a threshold value was arbitrarily decided, slightly higher than the error estimate under which the variance between Porro and modern topography can be considered acceptable.

In cases where the distortion was higher than the threshold, additional GCP were assigned by iteration until the desired effect was reached.

This was done for each single map section, which falls within a single or two or more plates. The process allowed us to minimize the distortion error as each plate is separate and can be geo-referenced singularly.

Subsequently, contour lines were digitalized through a linear geo-vector by assigning the relevant elevation above sea level. Once this operation was completed, the vertexes of these isolines were extracted.

In the hillside area (Circonvallazione a Monte, San Benigno Promontory, and Via Digione), this operation was sufficient and complete.

In floodplain areas (Sant'Agata Old Bridge and Polcevera Viaduct) where contour lines are not frequent or not visible due to the presence of buildings, another data source was represented by borehole stratigraphy (Figure 5) $[49,50]$.

In particular, the ancient interface surface between landfill material and natural rock/sediment was considered, but only in cases where the borehole stratigraphy indicated post-industrial landfills that included traces of cement, industrial bricks, etc.

Moreover, since riverbed areas in the Porro Map lack spot elevations, it was decided to conceptually match the old topographical surface with the current situation. This allowed us to bind the interpolation to the thalweg in order to maintain the morphology of typical cross-sections of Ligurian riverbeds.

Elevations of the current riverbed were extracted from LiDAR and assigned to the old riverbed as spot elevations. In this way, the same vector file gathered elevations extracted from contour lines: at the interface between landfill material and natural sediment/rock substrate and in the two riverbeds, bearing in mind that no significant natural process occurred, such as severe erosion or intense sediment accumulation due to flooding, that changed the floodplain terrace elevations between Porro's survey epoch and the late 1800s, when intense urban sprawls began, unlike the phenomena described in [58-60]. 


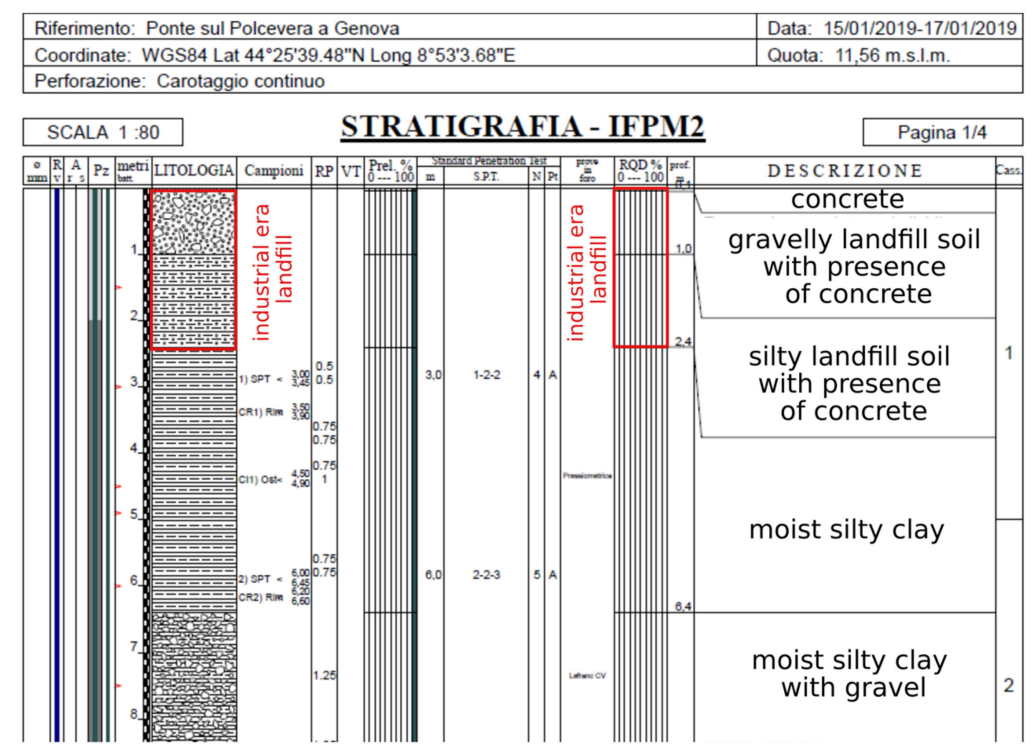

Figure 5. An example of a borehole with translated stratigraphy used for this research.

- Interpolation and DoDs with GRASS GIS

Since hand-drawn graphical elements of the Porro map have an equivalent resolution of $2 \mathrm{~m}$ ( $1 \mathrm{~mm}$ to the naked eye on a scale of 1:2'000), previously obtained elevation data were interpolated on a raster map with a 1-m resolution, also to reduce potential vertical errors due to horizontal offset between the old and current map, according to a methodology explained by Stoker et al. [61].

This was carried out in GRASS GIS through three different steps: (1) the v.surf.rst command [62], an algorithm based on spline with smooth and tension, used for preliminary interpolation that allowed us to convert elevations into a first raster dummy surface; (2) from this surface, a vector points cloud with casual location was extracted with the r.random command; (3) these points were interpolated a second time with the v.surf.rst command, obtaining a smooth surface, not affected by classic interpolation errors, such as quad-three, gradient gaps, etc. [63].

Moreover, once output raster maps of the five case studies were obtained, an assessment on vertical unreliability was carried out according to the following relation [54]:

$$
\varepsilon_{Z}=\varepsilon_{H} \cdot \tan \alpha
$$

where $\varepsilon_{Z}$ is the elevation error caused by horizontal offsets on a sloping surface, $\varepsilon_{H}$ is the horizontal error, and $\alpha$ is the local slope.

In slopes characterized by $\alpha<45^{\circ}$ gradient, potential vertical offsets between the old and current cartography are less than the horizontal one. In contrast, if angle $\alpha>45^{\circ}$, the quantification of the vertical offset is crucial as this is higher than the horizontal one.

The maximum vertical offset $\mathrm{RMSE}_{\mathrm{Zij} \text { MAX }}[64]$ was calculated, corresponding to the cell with the highest slope degree, according to relation (3), in order to have full knowledge of the limits of the extracted output:

$$
\mathrm{RMSE}_{\mathrm{Zij} \mathrm{MAX}}=\mathrm{RMSE}_{H} \tan \mathrm{S}_{\mathrm{ij}} \mathrm{MAX}
$$

where $R M S E_{H}$ is the horizontal error for the map, and $\mathrm{S}_{\mathrm{ij}} \mathrm{MAX}$ is the maximum slope in a i-row and $\mathrm{j}$-column grid cell of the output raster map.

Furthermore, sea level rise in the period 1884-2009 [65] was considered in order to quantify the heights' vertical offset between modern and 1830s sea level measurements. 
The resulting old DEMs were subtracted from the 1-m-resolution 2018 LiDAR of Genoa Municipality, obtaining the various DoDs, where positive areas correspond to fillings and negative ones to excavations [15].

\section{Results}

The methodology adopted produced the following results:

(1) Through an analysis of potential errors, the intrinsic accuracy of 19th-century cartography was quantified;

(2) Digital terrain models of early 19th-century topographical surfaces were obtained, allowing the quantification of urban transformations by underlying elevation differences.

From a first modelling process through MapAnalyst, it was possible to quantify potential errors by applying the linearized Helmert transformation, the affine transformation with five parameters, and the affine transformation with six parameters.

It was observed that the accuracy in old cartography increases in consolidated urban areas; this is due to the higher number of reference points that Porro and his team could use, compared to hilly areas. This also explains why the number of GCP couples is higher in plates of urban areas. This makes them more reliable than plates of rural areas characterized by less GCP couples. The GCP minimum number for each couple of images is 16 as shown in Table 1, alongside the error estimations for each plate.

Table 1. Georeferenced plate numbers with standard deviation, RMSE computed with various algorithms, and the number of used GCP.

\begin{tabular}{cccccccc}
\hline $\begin{array}{c}\text { Plate } \\
\text { Number }\end{array}$ & $\begin{array}{c}\text { STD DEV } \\
\text { (Helmert) }\end{array}$ & $\begin{array}{c}\text { RMSE } \\
\text { (Helmert) }\end{array}$ & $\begin{array}{c}\text { STD DEV } \\
\text { (Affine 5) }\end{array}$ & $\begin{array}{c}\text { RMSE } \\
\text { (Affine 5) }\end{array}$ & $\begin{array}{c}\text { STD DEV } \\
\text { (Affine 6) }\end{array}$ & $\begin{array}{c}\text { RMSE } \\
\text { (Affine 6) }\end{array}$ & $\mathbf{N}^{\circ}$ GCP \\
\hline 42 & 3.062 & 4.331 & 3.227 & 4.564 & 2.753 & 3.894 & 16 \\
52 & 2.620 & 3.705 & 2.529 & 3.577 & 2.399 & 3.393 & 22 \\
53 & 3.867 & 5.469 & 3.266 & 4.618 & 3.267 & 4.620 & 17 \\
62 & 2.683 & 3.795 & 2.617 & 3.702 & 2.573 & 3.639 & 20 \\
63 & 2.783 & 3.937 & 2.649 & 3.746 & 2.686 & 3.799 & 17 \\
72 & 2.892 & 4.090 & 3.084 & 4.362 & 3.305 & 4.674 & 16 \\
73 & 4.922 & 6.961 & 5.136 & 7.263 & 4.986 & 7.051 & 16 \\
\hline
\end{tabular}

An acceptable deviation threshold of $10 \mathrm{~m}$ on a $\mathrm{x}-\mathrm{y}$ plane between old and current cartography was arbitrarily established, a slightly higher value than the RMSE (Affine 5) of sheet $n^{\circ} 73$ (the least accurate and located in areas with no urban settlements at the time of Porro).

Interpolation obtained through spline with smoothing and tension at a 1-m resolution increases the smoothness of old topographical surfaces, generally characterized by a lower gradient than current ones. In addition, by interpolating contour lines it was possible to follow riverbeds and/or erosion landforms of ancient, often ephemeral, streams, now completely obliterated by anthropic landforms.

The total surface of the calculated raster maps is $1.79 \mathrm{~km}^{2}$, of which only $0.2 \%$ have a gradient $>45^{\circ}$, and the cell with the highest gradient has a value of $\alpha=84^{\circ}$ so that $\mathrm{RMSEZ}_{\mathrm{ijMAX}}=28.02 \mathrm{~m}$, obtained through relation (3) with $\mathrm{RMSE}_{\mathrm{H}}=4.09$ (Sheet 72, Helmert in Table 1).

In the remaining part (99.8\%), the vertical offset value is less than the horizontal one.

The case studies, all less than $2.5 \mathrm{~km}$ from the coastline, lie within $150 \mathrm{~m}$ asl. In particular, the Sant'Agata Old Bridge and Polcevera viaduct areas are respectively included between 5.2-60.3 $\mathrm{m}$ asl and 4.92-82.89 $\mathrm{m}$ asl, while via Digione and San Benigno Promontory are located respectively between $18.02-111.69 \mathrm{~m}$ asl and $10.02-92.41 \mathrm{~m}$ asl. Circonvallazione a Monte lies between 57.47 and $130.74 \mathrm{~m}$ asl.

The heights' vertical offset between modern and 1830s sea level measurements is about $25 \mathrm{~mm}$ with an average rate of $1.1 \mathrm{~mm} /$ year. Considering an average slope of $16.94^{\circ}$ for the old DEM hilly areas, as obtained only by the Porro's isolines interpolation, an offset 
of $0.25 \mathrm{~m}$ leads to an average $\mathrm{x}-\mathrm{y}$ shifting of $0.9 \mathrm{~m}$, which may be considered as a negligible value.

For what concerns the DoDs, outputs can be divided into three different macro-groups.

The first group is characterized by a high frequency of positive differences. This is the case of floodplain areas, including Sant'Agata Old Bridge (Figure 6) and Polcevera Viaduct (Figure 7). As already discussed, the preliminary assumption that old and current surfaces of Bisagno and Polcevera riverbeds precisely overlap means that the elevation difference in the DoDs equals to zero. Instead, there is a significant difference for what concerns current artificial embankments, which is maximum in their immediate proximity and tends to decrease with distance, reaching almost zero values near the foothill. The average thickness of the alluvial plain is around $2.45 \mathrm{~m}$.

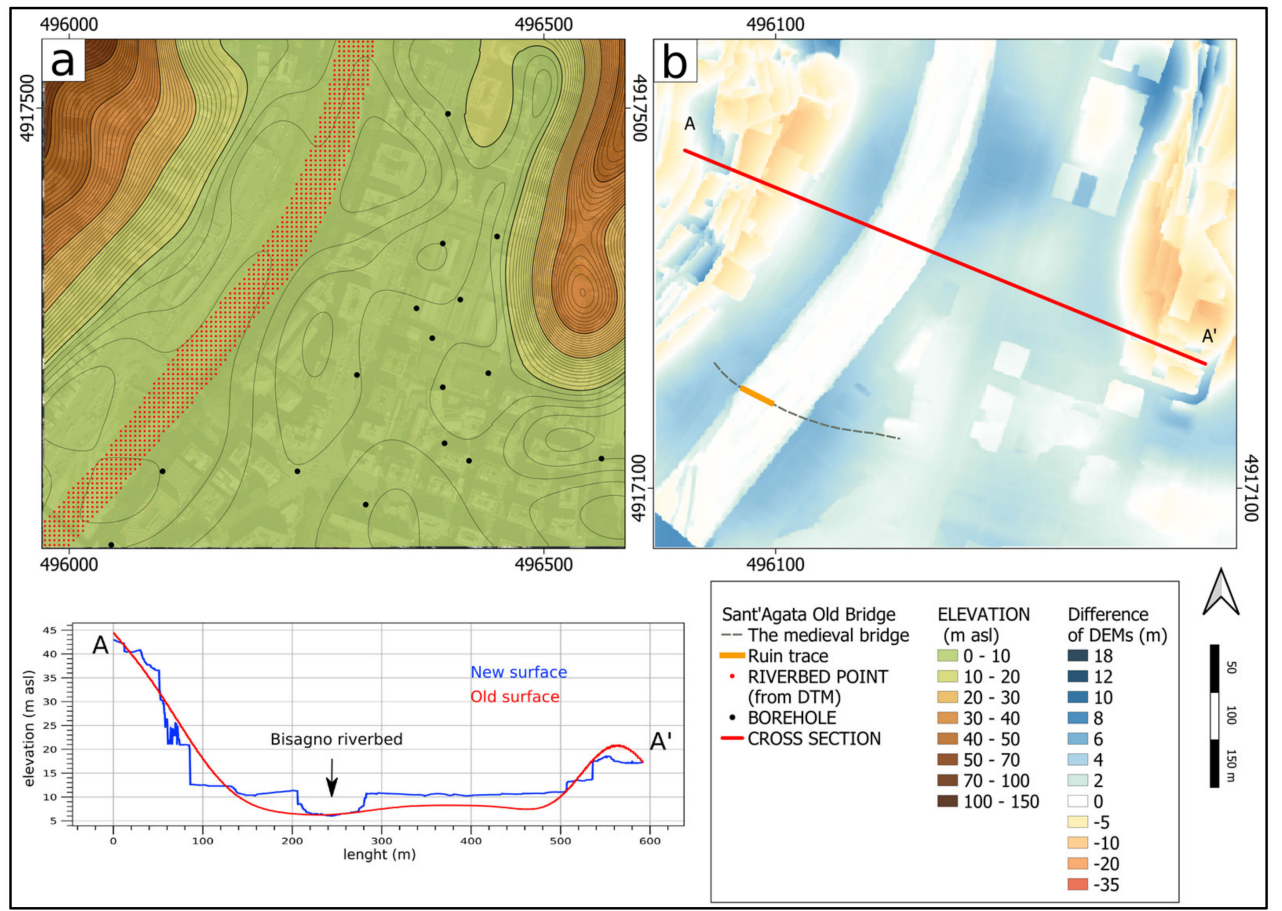

Figure 6. Sant'Agata Old Bridge: (a) Old surface; (b) DoD with the medieval and modern trace.

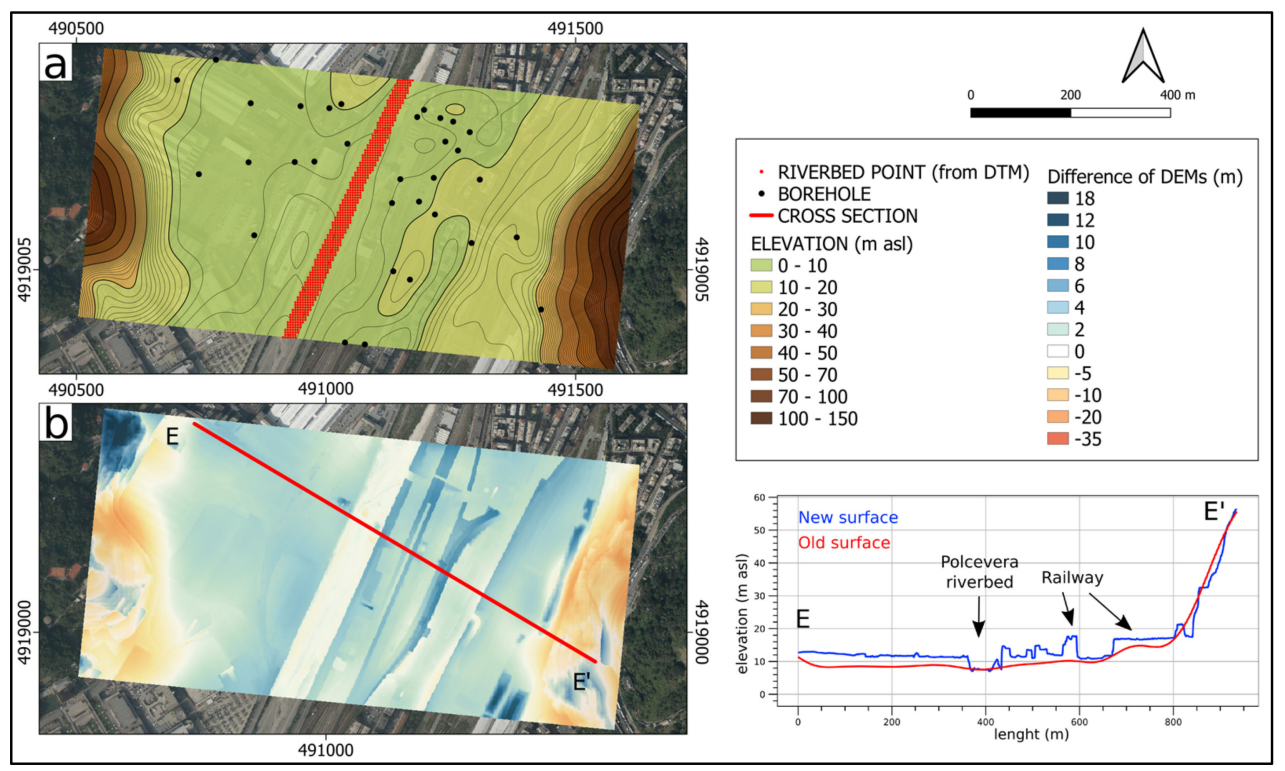

Figure 7. Polcevera Viaduct: (a) Old surface; (b) DoD. 
The case of Polcevera Viaduct is even more complex due to the numerous anthropic landforms (sensu Rosenbaum) (i.e., railway, industrial sites, etc.).

Along the slopes, local fillings with differences between 10-15 $\mathrm{m}$ are found.

The second group is characterized by a greater occurrence of negative differences. This is the case of via Digione and San Benigno Promontory (Figure 8). Except for slight positive differences of c. 2-3 $\mathrm{m}$ in the slope's upper side, significant negative differences, around $60-75 \mathrm{~m}$, are noticed.

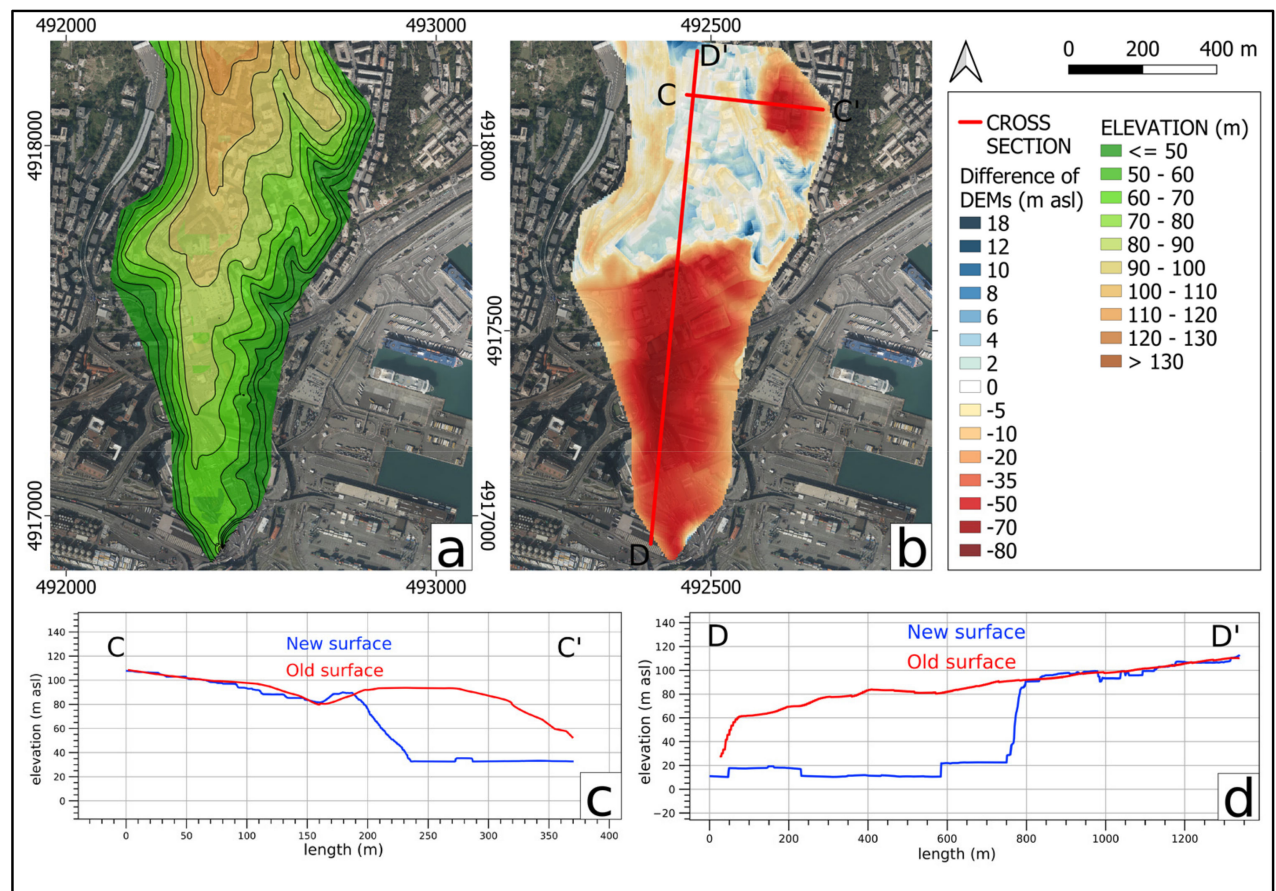

Figure 8. San Benigno Promontory and Via Digione: (a) Old surface; (b) DoD; (c) Via Digione cross-section; (d) San Benigno Promontory cross-section.

The third group is represented by Circonvallazione a Monte (Figure 9). In this case, it was not possible to identify areas characterized by a high frequency of positive and negative values. Amongst the negative differences there are values below $20 \mathrm{~m}$, while the positive ones can reach $12-15 \mathrm{~m}$. Compared to previous cases, areas with values around zero in Circonvallazione are rare. 


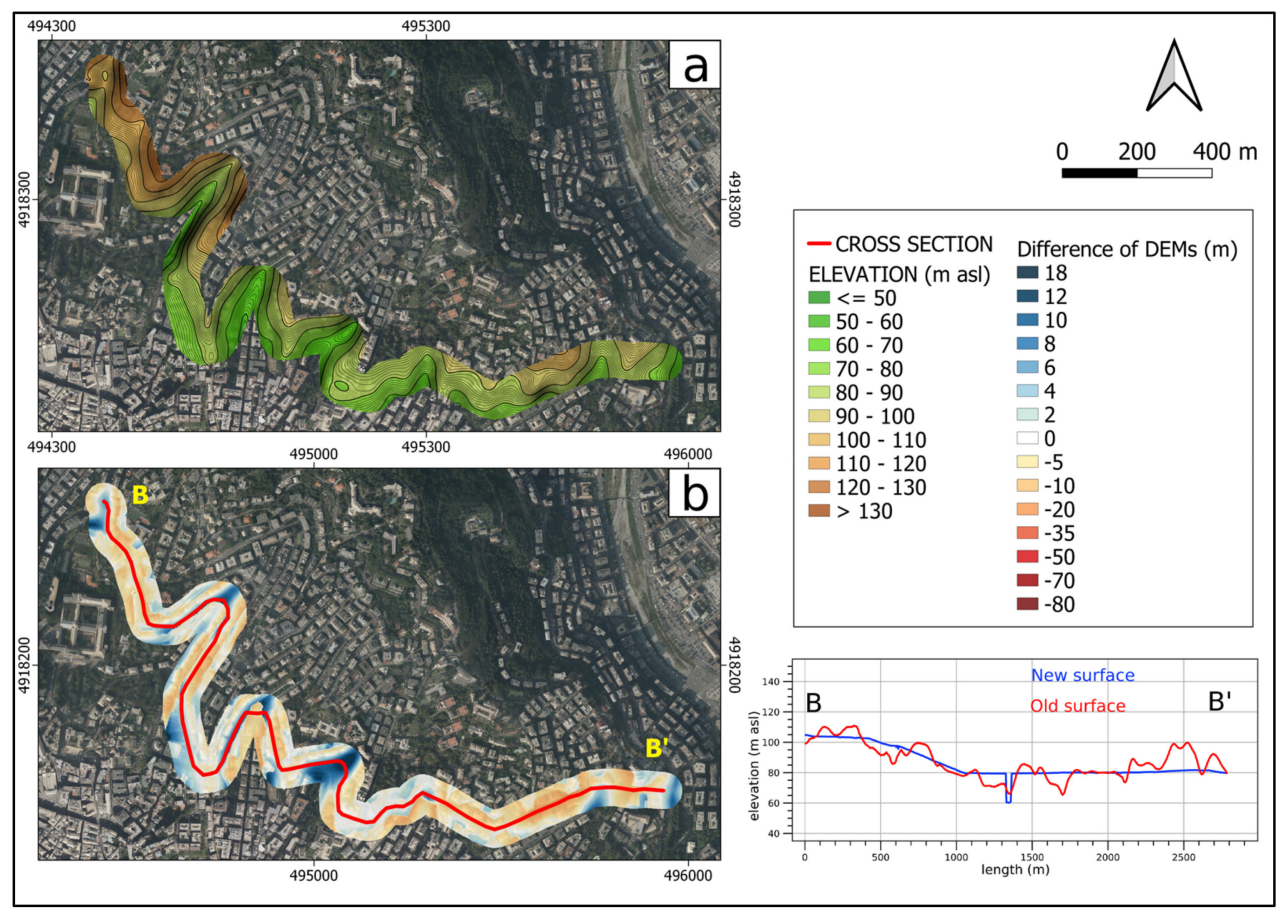

Figure 9. Circonvallazione a Monte: (a) Old surface; (b) DoD.

\section{Discussion}

The analysis shows how an average offset $<10 \mathrm{~m}$ between the current cartography and the "Carta Generale di Difesa di Genova" can be reached by repeating the geo-referencing process. This value can be considered acceptable to distinguish between natural and anthropic landforms at large-scale maps (1.10'000-1.5'000).

The difference between anthropic and natural landforms, however, is only visible for the period between present day and the second half of the 19th century. Anthropic landforms before this period can be easily confused with natural morphologies. For this reason, the Porro cartography and derived products can be integrated by using older cartographies, although these can lack geometrical accuracy. In addition, paintings, topographical views, and historical photographs can offer insights into past landscapes [66].

For instance, the raster of Figure 10a shows a gently sloping area along the left side of the stream with a regular pattern and constant NE-SW direction. From the analysis of the Porro cartography, it is not possible to establish whether this is a natural morphology or a filling landform of the period before 1848 [15].

However, the painting of Figure 10b, made in 1853 from previous en plein air sketches, shows that this can be a filling of the floodplain area of the Polcevera Stream confined by a consistent stone retaining wall. Here, starting from 1850, various railways lines connecting Genoa to northern Italy were established. The section of Figure $7 \mathrm{~b}$, near the viaduct, shows that the thickness of the two railway embankments is around $5 \mathrm{~m}$.

The area of Sant'Agata Old Bridge is also characterized by dense urbanization, although the evolution of anthropic and natural landforms is less complex. Here, a consistent filling dating back to the period between late 19th and early 20th century is found, related to the Bisagno Torrent narrowing. The bridge of Sant'Agata (Figures $6 \mathrm{~b}$ and 11a) was made in the medieval period along the track of the old Aurelia road and consisted of 28 arcades for a total length of $360 \mathrm{~m}$. Currently, the new bridges are only $50 \mathrm{~m}$ long, providing evidence of the significant narrowing of the Bisagno Stream riverbed [12]. Alongside Polcevera Stream, the Bisagno is currently one of the mostly exposed to geo-hydrological risk Italian rivers. Their narrowing is one of the reasons of the frequent flood events of the two streams. In the 1950-2015 period, 5 floods with discharge between 700 and $1000 \mathrm{~m}^{3} / \mathrm{s}$ occurred $[12,45,67]$. 

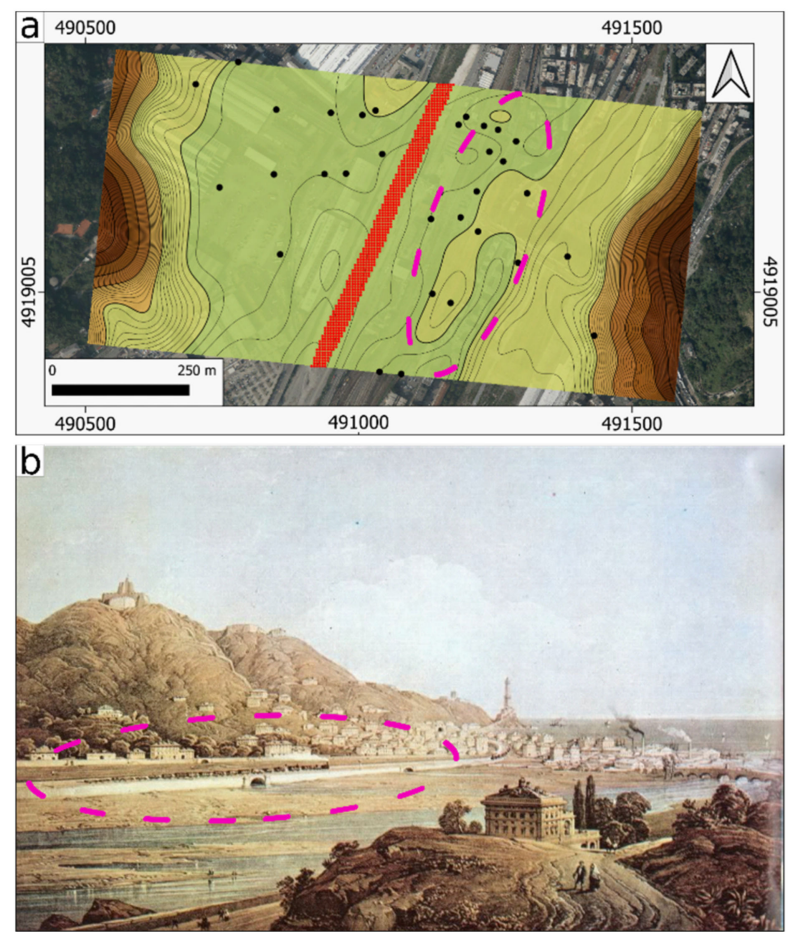

Figure 10. (a) The output of Polcevera viaduct, in purple dotted line the Campasso area; (b) Left bank, elevated area with embankment sustaining wall in the Campasso area (view by Carlo Bossoli, 1853).
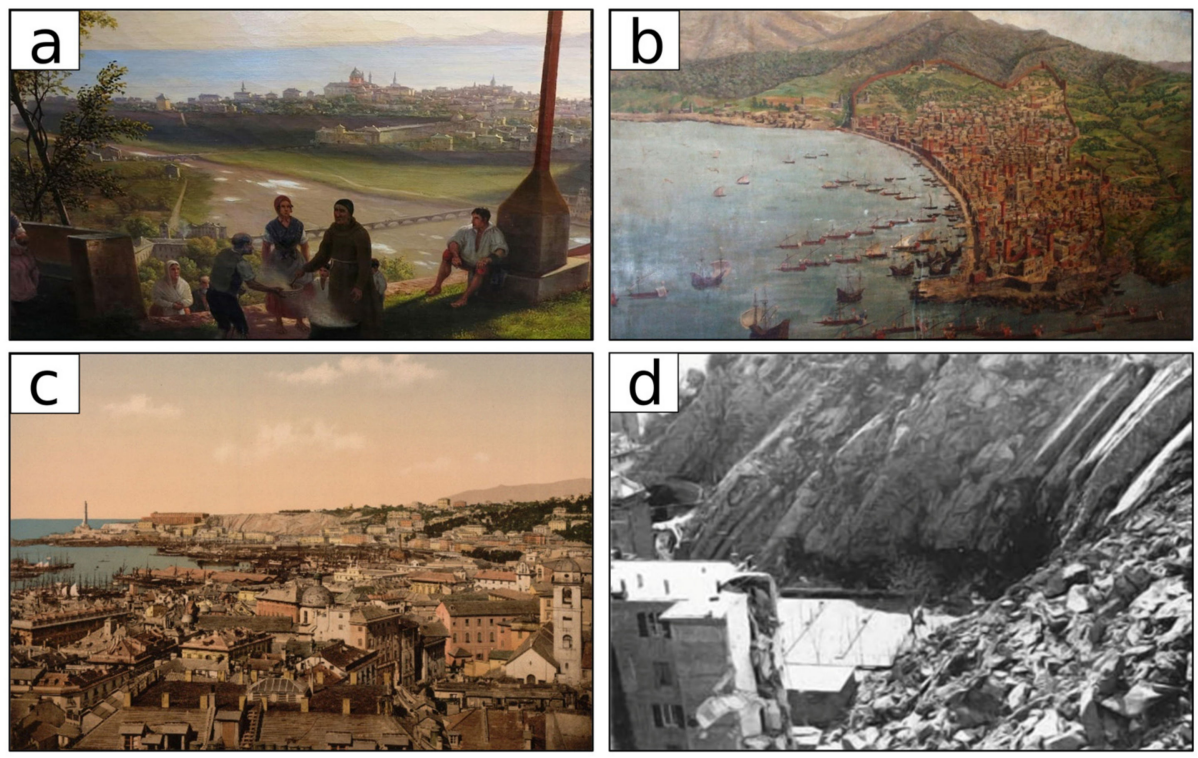

Figure 11. (a) Sant'Agata Bridge in the background (painting of Giuseppe Bisi, c. 1825); (b) Ancient Genoa: outside the city walls, over the hills, the site where Circonvallazione a Monte currently lies was characterized by a rural landscape (painting, unknown author, c. XV-XVII century); (c) San Benigno Promontory not yet excavated and the Lighthouse (La Lanterna) in the background; (d) Via Digione landslide (1968).

During intense rainfall events $(>50 \mathrm{~mm} / \mathrm{h},[44,45])$, minor sink-holes due to collapses of culvert-arches of underground streams took place [42], something that is also very likely to occur in the Circonvallazione a Monte area. 
Circonvallazione a Monte crosses an area characterized by 11 minor catchments less than $3 \mathrm{~km}^{2}$ in size [42]. As shown by Figure 9, filling and excavation anthropic landforms analyzed with DoD are quantitatively commensurate to current topography, constituted by excavations and significant decametric retaining walls (Figure 11b). These walls, built on limestone bedrock, are not monitored nor is their deterioration state known. Local building collapse episodes due to the subsidence of significant landfill materials thickness is indicated in small valleys that have been filled since the second half of the 19th century [42].

However, the most significant excavation case is San Benigno Promontory, where an entire slope was removed. Only considering the southernmost part of the slope, from the excavation face edge, more than $10.79 \cdot 10^{6} \mathrm{~m}^{3}$ of rock were removed between the late 19th century and 1960 (Figure 11c). This value was obtained by DoD in Figure 8, excluding the area of via Digione [68]. Here, another limestone quarry, completely excavated and characterized by the establishment of new buildings in the post-war period, was affected by a landslide in 1968, with 19 fatalities (Figure 11d).

Such a product, in addition to having multidisciplinary scientific interest, is also a useful tool for stratigraphy analysis of the buildings' foundation levels and for the production of civil protection maps [69] or multimedia products aimed at raising public awareness on geo-hydrological risk in urban contexts [70-72].

\section{Conclusions}

Digital image acquisition of analogic photographs of the "Carta Generale di Difesa di Genova" map; its error analysis, georeferencing, digitalization, and contour lines interpolation; and DEMs difference between the derived product and the current DTM (2018) allowed us to develop a specific methodology useful for the study of urban geomorphology. The analysis demonstrated that this specific old cartography can be compared with modern large-scale topographical maps. It provides evidence of the potential use of such historical material to identify and quantify anthropic landforms in urban geomorphology survey and mapping. In particular, it is worth mentioning cadastral maps with no elevations or contour lines and old views depicting past landscapes.

This analysis involved five sample areas that were compared with the topography of Ignazio Porro. The result can be divided into three different categories:

(1) Areas characterized by filling landforms prevalence;

(2) Areas characterized by excavation landforms prevalence;

(3) Areas with no filling or excavation landforms prevalence.

Potential further research can involve broader geographical areas and time frames; from a size point of view, the whole area of Genoa can be covered using the 77 plates made of the Porro map. Assessments of the city's morphometric changes can be carried out by analyzing more recent maps, for instance, geo-referencing and interpolating the IGM (Istituto Geografico Militare) 1:25'000 scale maps [14,71] produced between the late 19th and early 20th century in order to gain a precise city evolution with a 30-year interval.

This approach can be used for other cities that, like Genoa, are characterized by urban and architectural stratification worthy of being discovered and studied. This process would necessarily entail the use of a sufficiently old map or set of maps, which would depict with accuracy the landscape before urbanization took place.

Author Contributions: Conceptualization, Francesco Faccini and Martino Terrone; methodology, Martino Terrone and Guido Paliaga; software, Martino Terrone and Guido Paliaga; validation, Pietro Piana, Francesco Faccini and Marco D'Orazi; formal analysis, Martino Terrone; investigation, Martino Terrone and Francesco Faccini; resources, Martino Terrone and Francesco Faccini; data curation, Pietro Piana, writing—original draft preparation, Martino Terrone and Pietro Piana; writing—review and editing, Pietro Piana and Guido Paliaga; visualization, Marco D'Orazi; supervision, Francesco Faccini; project administration, Martino Terrone and Marco D'Orazi; funding acquisition, Martino Terrone and Francesco Faccini All authors have read and agreed to the published version of the manuscript. 
Funding: This research was financed by Programma Operativo Regione Liguria 2014-2020 - Fondo Sociale Europeo-Asse 3 "Istruzione e Formazione". RLOF18ASSRIC/60/1 “Tecnologie per il monitoraggio integrato e la mitigazione del rischio geomorfologico da frana nella gestione delle reti di sottoservizi" (Scientific coordinator: Francesco Faccini).

Conflicts of Interest: The authors declare no conflict of interest. The funders had no role in the design of the study; in the collection, analyses, or interpretation of data; in the writing of the manuscript, or in the decision to publish the results.

\section{References}

1. Hollis, G.E. The effect of urbanization on floods of different recurrence interval. Water Res. 1975, 11, 431-435. [CrossRef]

2. Brázdil, R.; Kundzewicz, Z.W.; Benito, G. Historical hydrology for studying flood risk in Europe. Hydrolog. Sci. J. 2006, 51, 739-764. [CrossRef]

3. Ho, L.T.; Umitsu, M. Micro-landform classification and flood hazard assessment of the Thu Bon alluvial plain, central Vietnam via an integrated method utilizing remotely sensed data. Appl. Geogr. 2011, 31, 1082-1093. [CrossRef]

4. Cunha, N.S.; Magalhães, M.R.; Domingos, T.; Abreu, M.M.; Küpfer, C. The land morphology approach to flood risk mapping: An application to Portugal. J. Environ. Manag. 2017, 193, 172-187. [CrossRef]

5. Viero, D.P.; Roder, G.; Matticchio, B.; Defina, A.; Tarolli, P. Floods, landscape modifications and population dynamics in anthropogenic coastal lowlands: The Polesine (northern Italy) case study. Sci. Total Environ. 2019, 651, 1435-1450. [CrossRef]

6. Canuti, P.; Casagli, N.; Pellegrini, M.; Tosatti, G. Geo-hydrological hazards. In Anatomy of an Orogen, the Apennines and Adjacent Mediterranean Basins; Vai, G.B., Martini, I.P., Eds.; Springer: Dordrecht, The Netherlands, 2019; Chapter 28; pp. 513-532.

7. Paliaga, G.; Faccini, F.; Luino, F.; Turconi, L.; Bobrowsky, P. Geomorphic processes and risk related to a large landslide dam in a highly urbanized Mediterranean catchment (Genova, Italy). Geomorphology 2019, 327, 48-61. [CrossRef]

8. Del Monte, M.; D’Orefice, M.; Luberti, G.M.; Marini, R.; Pica, A.; Vergari, F. Geomorphological classification of urban landscapes: The case study of Rome (Italy). J. Maps. 2016, 12, 178-189. [CrossRef]

9. Vergari, F.; Luberti, G.M.; Pica, A.; Del Monte, M. Geomorphology of the historic centre of the Urbs (Rome, Italy). J. Maps. 2020, 1-12. [CrossRef]

10. Bathrellos, G.D. An overview in urban geology and urban geomorphology. Bull. Geol. Soc. Greece 2018, 40, 1354-1364. [CrossRef]

11. Zwoliński, Z.; Hildebrandt-Radke, I.; Mazurek, M.; Makohonienko, M. Anthropogeomorphological metamorphosis of an urban area in the postglacial landscape: A case study of Poznań city. In Urban Geomorphology: Landforms and Processes in Cities, 1st ed.; Thornbush, M., Allen, C., Eds.; Elsevier: Amsterdam, The Netherlands, 2018; pp. 55-77.

12. Luino, F.; Paliaga, G.; Roccati, A.; Sacchini, A.; Turconi, L.; Faccini, F. Anthropogenic changes in the alluvial plains of the Tyrrhenian Ligurian basins. Rend. Online Soc. Geol. Ital. 2019, 48, 10-16. [CrossRef]

13. Brandolini, P.; Cappadonia, C.; Luberti, G.M.; Donadio, C.; Stamatopoulos, L.; Di Maggio, C.; Del Monte, M. Geomorphology of the Anthropocene in Mediterranean urban areas. PPG Earth Environ. 2020, 44, 461-494. [CrossRef]

14. Mandarino, A.; Faccini, F.; Terrone, M.; Paliaga, G. Anthropogenic landforms and geo-hydrological hazards of the Bisagno Stream catchment (Liguria, Italy). J. Maps. 2021, 118-131. [CrossRef]

15. Rosenbaum, M.S.; McMillan, A.A.; Powell, J.H.; Cooper, A.H.; Culshaw, M.G.; Northmore, K.J. Classification of artificial (man-made) ground. Eng. Geol. 2003, 69, 399-409. [CrossRef]

16. Tarolli, P.; Cao, W.; Sofia, G. From features to fingerprints: A general diagnostic framework for anthropogenic geomorphology PPG Earth Environ. 2019, 43, 95-128. [CrossRef]

17. Łajczak, A.; Zarychta, R.; Wałek, G. Changes in the topography of Krakow city centre, Poland, during the last millennium. J. Maps. 2010, 1-8. [CrossRef]

18. El May, M.; Dlala, M.; Chenini, I. Urban geological mapping: Geotechnical data analysis for rational development planning. Eng. Geol. 2010, 116, 129-138. [CrossRef]

19. Huggenberger, P.; Epting, J. Urban Geology: Process-Oriented Concept for Adaptive and Integrated Resource Management; Springer: Dordrecht, The Netherlands, 2011. [CrossRef]

20. Luberti, G.M.; Vergari, F.; Marini, R.; Pica, A.; Del Monte, M. Anthropogenic modifications to the drainage network of Rome (Italy): The case study of the Aqua Mariana. Alp. Mediterr. Quat. 2018, 31, 119-132. [CrossRef]

21. Luberti, G.M.; Vergari, F.; Pica, A.; Del Monte, M. Estimation of the thickness of anthropogenic deposits in historical urban centres: An interdisciplinary methodology applied to Rome (Italy). Holocene 2020, 29, 158-172. [CrossRef]

22. Cajori, F. History of Determinations of the Heights of Mountains. Isis 1929, 12, 482-514. [CrossRef]

23. Fuchs, R.; Verburg, P.H.; Clevers, J.G.P.W.; Herold, M. The potential of old maps and encyclopaedias for reconstructing historic European land cover/use change. Appl. Geogr. 2015, 59, 43-55. [CrossRef]

24. Loran, C.; Haegi, S.; Ginzler, C. Comparing historical and contemporary maps-a methodological framework for a cartographic map comparison applied to Swiss maps. Int. J. Geogr. Inf. Sci. 2018, 32, 2123-2139. [CrossRef]

25. Laxton, P. The Geodetic and topographical evaluation of English county maps, 1740-1840. Cartogr. J. 1976, 13, 37-54. [CrossRef]

26. Rann, K.; Johnson, R.S. Chasing the line: Hutton's contribution to the invention of contours. J. Maps 2019, 15, 48-56. [CrossRef]

27. Pelletier, M. Cartography and power in France during the seventeenth and eighteenth centuries. Cartogr. Int. J. Geogr. Inf. Geovisualization 1998, 35, 41-53. [CrossRef] 
28. Hewitt, R. Map of a Nation: A Biography of the Ordinance Survey; Granta Publications: London, UK, 2011.

29. Borgato, M.T. Great hydraulic works of French engineers during the Napoleonic Period in Italy. In Proceedings of the XXIII ICHST (International Congress of History of Science and Technology), Budapest, Hungary, 23-30 July 2009; Omigraf Ltd.: Warszawa, Poland, 2009; Volume 1, p. 143.

30. Maciuk, K.; Apollo, M.; Mostowska, J.; Lepeška, T.; Poklar, M.; Noszczyk, T.; Kroh, P.; Krawczyk, A.; Borowski, L.; PavlovčičPrešeren, P. Altitude on Cartographic Materials and Its Correction According to New Measurement Techniques. Remote Sens. 2021, 13, 444. [CrossRef]

31. Apollo, M.; Mostowska, J.; Maciuk, K.; Wengel, Y.; Jones, T.E.; Cheer, J.M. Peak-bagging and cartographic misrepresentations: A call to correction. Curr. Issues Tour. 2020, 1-6. [CrossRef]

32. Cazzani, A.; Brumana, R.; Zerbi, C.M. The geo-referenced XIX century cartography: An analysis tool and a project reference for the preservation and management of built and landscape heritage. Int. Arch. Photogramm. Remote Sens. Spatial Inf. Sci 2019, XLII-2/W11, 395-402. [CrossRef]

33. Guarducci, A.; Tarchi, G. The first geodetic map of the Grand Duchy of Tuscany georeferencing and applicated studies. $e$ Perimetron 2020, 15, 168-182.

34. Faccini, F.; Robbiano, A.; Roccati, A.; Angelini, S. Engineering geological map of the Chiavari city area (Liguria, Italy). J. Maps 2012, 8, 41-47. [CrossRef]

35. Brandolini, P.; Faccini, F.; Paliaga, G.; Piana, P. Man-made landforms survey and mapping of an urban historical center in a coastal Mediterranean environment. Geogr. Fis. Dinam. Quat. 2018, 41, 23-34.

36. Laureti, L. A data archives of historical cartography. Boll. Dell'associazione Ital. Cartogr. 2010, 138, 101-108.

37. Savino, S.; Rumor, M.; Congiu, S. Automated cartographic generalization in Italy. ISPRS Int. Arch. Photogramm. Remote Sens. Spatial Inf. Sci. 2011, XXXVIII-4/C21, 109-114. [CrossRef]

38. Abbate, E.; Bortolotti, V.; Passerini, P.; Sagri, M. Introduction to the geology of the Northern Apennines. Sed. Geol. 1970, 4, 207-249. [CrossRef]

39. APAT, Regione Liguria. Foglio 213230‘Genova'della Carta Geologica d’Italia alla Scala 1:50.000 [Sheet n. 213230 ‘Genova’of the Italian Geological Map at1:250.000 scale]. Selca Editore Firenze. 2008. Available online: http://www.isprambiente.gov.it/Media/ carg/213_GENOVA/Foglio.html (accessed on 30 March 2021).

40. Capponi, G.; Crispini, L.; Federico, L.; Piazza, M.; Fabbri, B. Late Alpine tectonics in the Ligurian Alps: Constraints from the Tertiary Piedmont Basin conglomerates. Geol. J. 2009, 44, 211-224. [CrossRef]

41. Sacchini, A.; Imbrogio Ponaro, M.; Paliaga, G.; Piana, P.; Faccini, F.; Coratza, P. Geological Landscape and Stone Heritage of the Genoa Walls Urban Park and surrounding area (Italy). J. Maps 2018, 14, 528-541. [CrossRef]

42. Faccini, F.; Giardino, M.; Paliaga, G.; Perotti, L.; Brandolini, P. Urban geomorphology of Genoa old city (Italy). J. Maps 2020, 1-14. [CrossRef]

43. Brancucci, G.; Paliaga, G. Geomorphic characterization of the main drainage basins of maritime Liguria (Italy)—Preliminary results. Geogr. Fis. Din. Quat. 2005, VII, 59-67.

44. Epstein, S.A. Genoa and the Genoese; University of North Carolina Press: Chapel Hill, NC, USA, 1996; pp. $958-1528$.

45. Paliaga, G.; Faccini, F.; Luino, F.; Roccati, A.; Turconi, L. A clustering classification of catchment anthropogenic modification and relationships with floods. Sci. Tot. Environ. 2020, 740, 139915. [CrossRef] [PubMed]

46. Faccini, F.; Paliaga, G.; Piana, P.; Sacchini, A.; Watkins, C. The Bisagno stream catchment (Genoa, Italy) and its major floods: Geomorphic and land use variations in the last three centuries. Geomorphology 2016, 273, 14-27. [CrossRef]

47. Paliaga, G.; Luino, F.; Turconi, L.; Marincioni, F.; Faccini, F. Exposure to Geo-hydrological hazards of the Metropolitan area of Genoa, Italy: A Multi-Temporal analysis of the Bisagno Stream. Sustainability 2020, 12, 1114. [CrossRef]

48. Piana, P.; Faccini, F.; Luino, F.; Paliaga, G.; Sacchini, A.; Watkins, C. Geomorphological landscape research and flood management in a heavily modified Tyrrhenian catchment. Sustainability 2019, 11, 4594. [CrossRef]

49. Rossi, L. Again on Representation of Relief. The French centrality end an early Italian case (the 19th century). Geotema 2018, 58, 70-79.

50. Geoportale Regione Liguria-Sondaggi e Stratigrafie. Available online: http://srvcarto.regione.liguria.it/geoviewer2/pages/ apps/geoportale/index.html?id=1030. (accessed on 30 March 2021).

51. Commissario Straordinario Ricostruzione Genova-Studi Ambientali. Available online: http:/ /www.commissario.ricostruzione. genova.it/contenuto/studi-ambientali (accessed on 30 March 2021).

52. Williams, R. DEMs of difference. In Geomorphological Techniques; BSG: London, UK, 2012; Volume 2.

53. McMillan, A.A.; Powell, J.H. Classification of artificial (man-made) ground and natural superficial deposits applications to geological maps and datasets in the UK. BGS Rock Classifi. Scheme 1999, 4, RR99-04.

54. Fiz, I.; Orengo, H.A. Simulating Communication Routes in Mediterranean Alluvial Plains. In Proceedings of the Layers of Perception: The 35th International Conference on Computer Applications and Quantitative Methods in Archaeology (CAA), Berlin, Germany, 2-6 April 2007; Posluschny, A., Lambers, K., Herzog, I., Eds.; Rudolf Habelt: Bonn, Germany, 2008 ; pp. 309-315.

55. Molewski, P.; Juśkiewicz, W. An attempt to reconstruct the primary relief of the Old Town of Torun and its close suburbs on the basis of the geological and historical geoinformation. Landf. Anal. 2014, 25, 115-124. [CrossRef]

56. Cheung, C.K.; Shi, W. Estimation of the positional uncertainty in line simplification in GIS. Cart. J. 2004, 41, 37-45. [CrossRef]

57. Zitová, B.; Flusser, J. Image registration methods: A survey. Image Vision. Comput. 2003, 21, 977-1000. [CrossRef] 
58. Fara, A. La Carta di Ignazio Porro: Cartografia per L'architettura Militare Nella Genova Della Prima Metà Dell'ottocento [Ignazio Porro's Map: Cartography for Military Architecture in Genoa in the First Half of the Nineteenth Century]; Stato maggiore dell'esercito-Ufficio storico: Rome, Italy, 1986.

59. Leopold, L.B.; Wolman, M.G. River Channel Patterns: Braided, Meandering, and Straight; Professional Paper 282-B; U.S. Government Printing Office: Washington, DC, USA, 1957.

60. Zwolinski, Z. Sedimentology and geomorphology of overbank flows on meandering river floodplains. Geomorphology 1992, 4, 367-379. [CrossRef]

61. Fassosi-Andrade, A.C.; Cauduro Dias de Paiva, R.; Fleischmann, A.S. Lake Topography and Active Storage from Satellite Observations of Flood Frequency. Water Resour. Res. 2020, 56. [CrossRef]

62. Stoker, J.; Harding, D.; Parrish, J. The need for a national LiDAR dataset Photogrammetric. Eng. Remote Sens. 2008, 74, 1066-1068.

63. Mitàsova, H.; Mitàs, L. Interpolation by Regularized Spline with Tension: I. Theory and Implementation. Math. Geol. 1993, 25, 641-655. [CrossRef]

64. De Floriani, L.; Puppo, E. Multiresolution Models for Terrain Surface Description. Vis. Comput. 1996, 12, 317-345. [CrossRef]

65. James, L.A.; Hodgson, M.E.; Ghoshal, S.; Latiolais, M.M. Geomorphic change detection using historic maps and DEM differencing: The temporal dimension of geospatial analysis. Geomorphology 2012, 137, 181-198. [CrossRef]

66. Moatti, J.P.; Thiébault, S. The Mediterranean Region under Climate Change; IRD Éditions: Marseilles, France, 2016. [CrossRef]

67. Piana, P.; Watkins, C. Questioning the view: Historical geography and topographical art. Geogr. Compass 2020, 14 , e12483. [CrossRef]

68. Faccini, F.; Luino, F.; Sacchini, A.; Turconi, L. Flash flood events and urban development in Genoa (Italy): Lost in translation. In Engineering Geology for Society and Territory; Lollino, G., Manconi, A., Guzzetti, F., Culshaw, M., Bobrowsky, P., Luino, F., Eds.; Springer International Publishing: Cham, Switzerland, 2015; Volume 5, pp. 797-801. [CrossRef]

69. Brandolini, P.; Cevasco, A.; Firpo, M.; Robbiano, A.; Sacchini, A. Geo-hydrological risk management for civil protection purposes in the urban area of Genoa (Liguria, NW Italy). Nat. Haz. Earth Sys. 2012, 12, 943-959. [CrossRef]

70. Lanza, S.G. Flood hazard threat on cultural heritage in the town of Genoa (Italy). J. Cult. Herit. 2003, 4, 159-167. [CrossRef]

71. Bandecchi, A.E.; Pazzi, V.; Morelli, S.; Valori, L.; Casagli, N. Geo-hydrological and seismic risk awareness at school: Emergency preparedness and risk perception evaluation. Int. J. Disaster Risk Reduct. 2019, 40, 101280. [CrossRef]

72. Faccini, F.; Robbiano, A.; Sacchini, A. Geomorphic hazards and intense rainfall: The case study of the Recco Stream catchment (Eastern Liguria, Italy). Nat. Haz. Earth Syst. Sci. 2012, 12, 893-903. [CrossRef] 